\title{
A Comparison in Thermal-Hydraulics Analysis of PWR-1000 Using Fixed and Temperature Function of Thermal Conductivity
}

\author{
Muh. Darwis Isnaini ${ }^{1}$, Etty Mutiara ${ }^{2}$ \\ ${ }^{1}$ Center for Safety Technology and Nuclear Reactor-BATAN \\ Gedung 80, Puspiptek, Serpong, Tangerang Selatan, BANTEN, 15310, Indonesia \\ ${ }^{2}$ Center for Nuclear Fuel Technology-BATAN \\ Gedung 20, Puspiptek, Serpong, Tangerang Selatan, BANTEN, 15310, Indonesia
}

\begin{tabular}{l}
\hline ARTICLE INFORM ATION \\
\hline Article History: \\
Received: \\
16 June 2016 \\
Received in revised form: \\
11 August 2016 \\
Accepted: \\
16 September 2016
\end{tabular}

\section{Keywords:}

Comparison

Thermal-hydraulic

Thermal conductivity

Fixed and temperature function

\begin{abstract}
A COMPARISON IN THERMAL-HYDRAULICS ANALYSIS OF PWR-1000 USING FIXED AND TEMPERATURE FUNCTION OF THERMAL CONDUCTIVITY. A study to analyze the influence of the fuel-cladding's thermal conductivity on the sub-channel of pressurized water reactor 1000 (PWR-1000) using COBRA-EN computer code was conducted. The purpose of this research is to gain complete understanding of sub-channel thermal-hydraulic aspects related to fuel performance, especially the appropriate range of thermal conductivity of $\mathrm{UO}_{2}$ fuel $\left(k_{f}\right)$ and zircaloy- 4 cladding $\left(k_{c}\right)$ in order to obtain an accurate sub-channel analysis related to its safety behavior. The research was conducted by comparing the calculation with the combination values of the fixed $k_{f}$ and $k_{c}$, as well as the calculation using $k_{f}$ and $k_{c}$ as temperature function. The fixed $k_{f}$ using in this calculation were $5.26 \mathrm{~W} / \mathrm{m} . \mathrm{K}, 3.85 \mathrm{~W} / \mathrm{m} . \mathrm{K}$, $3.60 \mathrm{~W} / \mathrm{m} . \mathrm{K}, 3.18 \mathrm{~W} / \mathrm{m} . \mathrm{K}, 2.90 \mathrm{~W} / \mathrm{m} . \mathrm{K}, 2.53 \mathrm{~W} / \mathrm{m} . \mathrm{K}$ and $2.34 \mathrm{~W} / \mathrm{m} . \mathrm{K}$, while the $k_{c}$ were 13.0 $\mathrm{W} / \mathrm{m} . \mathrm{K}, 15.57 \mathrm{~W} / \mathrm{m} . \mathrm{K}, 16.75 \mathrm{~W} / \mathrm{m} . \mathrm{K}, 17.94 \mathrm{~W} / \mathrm{m} . \mathrm{K}$ and $18.69 \mathrm{~W} / \mathrm{m} . \mathrm{K}$. The maximum fuel center line temperature using $k_{f}$ and $k_{c}$ as temperature function (MATPRO) for hot subchannel was $1717.65^{\circ} \mathrm{C}$ and taken as the reference in accepting the calculation result using fixed thermal conductivity. The analysis was accepted, if the deviation between both temperature was in the range of $-10 \%$ to $10 \%$. This analysis results for hot sub-channel was accepted for the calculation using value of $k_{f}$ in the range of $3.18-2.90 \mathrm{~W} / \mathrm{m} . \mathrm{K}$ for all all variation value of $k_{c}$ While the calculation using value of $k_{f}$ of $2.53 \mathrm{~W} / \mathrm{m} . \mathrm{K}$ was accepeted for value of $k_{c}$ in the range of $16.76-18.69 \mathrm{~W} / \mathrm{m} . \mathrm{K}$.
\end{abstract}

\begin{abstract}
ABSTRAK
PERBANDINGAN ANTARA ANALISIS TERMOHIDROLIKA PWR-1000 MENGGUNAKAN KONDUKTIVITAS TERMAL TETAP DAN SEBAGAI FUNGSI TEMPERATUR. Telah dilakukan penelitian untuk mengetahui pengaruh nilai konduktivitas termal kelongsong dan bahan bakar dalam analisis termohidrolika sub-kanal reaktor air tekan 1000 (PWR-1000) menggunakan kode COBRA-EN. Penelitian ini bertujuan untuk mendapatkan pemahaman yang komplit pada aspek termohidrolika sub-kanal yang berkaitan dengan unjuk kerja bahan bakar, khususnya rentang nilai konduktivitas termal bahan bakar $\mathrm{UO}_{2}\left(k_{f}\right)$ dan bahan kelongsong zircaloy-4 $\left(k_{c}\right)$ yang tepat agar diperoleh analisis yang akurat. Penelitian dilakukan dengan cara membandingkan perhitungan menggunakan kombinasi nilai $k_{f}$ dan $k_{c}$ yang konstan (tetap), dengan perhitungan menggunakan $k_{f}$ dan $k_{c}$ sebagai fungsi temperatur. Nilai $k_{f}$ konstan yang digunakan sebesar $5,26 \mathrm{~W} / \mathrm{m} . \mathrm{K}, 3,85 \mathrm{~W} / \mathrm{m} . \mathrm{K}, 3,60 \mathrm{~W} / \mathrm{m} . \mathrm{K}$, $3,18 \mathrm{~W} / \mathrm{m} . \mathrm{K}, 2,90 \mathrm{~W} / \mathrm{m} . \mathrm{K}, 2,53 \mathrm{~W} / \mathrm{m} . \mathrm{K}$ dan 2,34 W/m.K, sedangkan nilai $k_{c}$ sebesar 13,0 $\mathrm{W} / \mathrm{m} . \mathrm{K}, 15,57 \mathrm{~W} / \mathrm{m} . \mathrm{K}, 16,75 \mathrm{~W} / \mathrm{m} . \mathrm{K}, 17,94 \mathrm{~W} / \mathrm{m} . \mathrm{K}$ dan $18,69 \mathrm{~W} / \mathrm{m} . \mathrm{K}$. Temperatur maksimum pusat bahan bakar untuk sub-kanal panas menggunakan $k_{f}$ dan $k_{c}$ sebagai fungsi temperatur (MATPRO) sebesar $1717,65^{\circ} \mathrm{C}$ dan diambil sebagai acuan penerimaan hasil perhitungand engan nilai konduktivitas termal konstan. Analisis diterima, jika deviasi antara kedua temperatur berada antara $-10 \%$ sampai $10 \%$. Hasil analisis pada sub-kanal panas dapat diterima untuk perhitungan menggunakan $k_{f}$ antara 3,18 dan 2,90 W/m.K untuk seluruh variasi nilai $k_{c}$. Sedangkan perhitungan dengan $k_{f}$ sebesar $2,53 \mathrm{~W} / \mathrm{m} . \mathrm{K}$ dapat diterima untuk nilai $k_{c}$ antara 16,76 dan $18,69 \mathrm{~W} / \mathrm{m} . \mathrm{K}$.

Kata kunci: perbandingan, termohidrolika, konduktivitas termal, tetap dan fungsi temperatur.
\end{abstract}

\section{INTRODUCTION}

The analysis of core and sub-channel of a Nuclear Power Plant (NPP) has been

*Penulis korespodensi.

E-mail: darwis@batan.go.id performed in order to gain complete understanding of core thermal-hydraulic aspects related to fuel performance and NPP 
safety behavior. This analysisis conducted by a calculation using computer codes to obtain a prediction of thermal hydraulic performance of a NPP. An accurate prediction of thermal hydraulic performance of a NPP is crucial in its design and operation for both economic and safety reasons[1] especially the prediction of the peak temperatures of the fuel rods and coolant. These predictions depend to fuel meat, cladding and coolant outlet temperature in the steady state or transient conditions [2].

Many researches on thermal-hydraulic of a NPP had been conducted by using fixed value for thermal conductivity. These researches were done on Pressurized Water Reactor 1000 MWe (PWR-1000) and Advanced PWR-1000 (AP1000) reactor core using COBRA-EN code related to evaluation on sub-channel design thermal-hydraulic [3], grid-spacer effect[4] and the effect of radialaxial power fluctuations[5]. In this study, COBRA-EN code used thermal conductivity data of $\mathrm{UO}_{2}$ fuel of $3.60 \mathrm{~W} / \mathrm{m} .{ }^{\circ} \mathrm{C}[3,4]$ and the thermal conductivity of Zircaloy-4 cladding of $18.69 \mathrm{~W} / \mathrm{m} .{ }^{\circ} \mathrm{C}[3-5]$. COBRA-EN code is also used on capability enhancement for VVER reactor calculation[2], deterministic optimum loading pattern[6], thermal-hydraulics modeling of nanofluids[7], sub-channel analysis of nano fluid[8] and other research in VVER-1000 reactor [9-11].

In an NPP, the heat generation in the fuel is influenced by the position of fuel assemblies on the reactor core. Heat generation in the fuel assemblies at central position of core tends to be higher than at the edge position in radial position, and tends to be higher than in the top and bottom of active core in axial position. The highest, averages and lowest heat generation of fuel assemblies each known as hot channel, average channel and cold channel, respectively. The heat generation in the fuel assemblies and the physical properties of the fuel, cladding and coolant will determine their temperatures. These physical properties such as the specific heat capacity $\left(C_{p}\right)$ and the coefficient of thermal conductivity $(k)$ of fuels and claddings are the ability of fuel and cladding to transfer heat to coolant and influenced by the temperature itself. Consequently, the differences of heat generation and physical properties will result the temperature differences in the fuel meat, cladding and coolant.

In order to obtain an accurate PWR1000 sub-channel thermal-hydraulic analysis related to safety behavior, the analysis of core and sub-channel thermal-hydraulicof a PWR1000 was conducted in which the core calculation was done by using COBRA-EN code. This analysisis performed in order to gain an understanding of sub-channel thermal-hydraulic aspect related to fuel performance in effective heat transfer processing, especially the appropriate range of thermal conductivity of $\mathrm{UO}_{2}$ fuel and Zircaloy-4 cladding. The analysis of subchannel thermal-hydraulic using codes often encountered obstacles, e.g. the limitation of code in calculating physical properties as a temperature function such as conductivity and heat capacity of fuel and cladding. This limitations effectless accurate calculation results. Therefore, the sensitivity analysis of fuel and cladding thermal conductivity on subchannel thermal-hydraulic characteristics of PWR-1000 was conducted to obtain more accurate analysis results. The previous study discussed that the increase in the fixed value of the thermal conductivity of the fuel provided insignificant effect on reducing the peak cladding temperature during the accident[1]. In this research, the analysis was accepted if deviation between temperature values using fixed and temperature function of thermal conductivity was in the rangeof-10\% to $10 \%$ [12] to avoid inaccuracy.

The purpose of this research is making the sub-channel thermal-hydraulic analysis of AP1000 accurate, with the emphasizing on the effect of fuel and cladding's fixed thermal conductivity value on temperature distribution of coolant, cladding and fuel. The accuration of the analysis was shown from the comparison the results between the calculation using fixed value of thermal conductivity and the calculations using thermal conductivity as temperature functions. The accurate analysis using fixed thermal conductivity were needed for future research, because several codes for analyze the transient condition, such as EUREKA code, are only able to use fixed thermal conductivity as the input. Hence, the accurate analysis using fixed thermal conductivity is very 
important. This analysis was conducted on steady state nominal power condition. The calculations using fixed value of thermal conductivity were conducted using COBRAEN code, by inputting proper value. While the calculation using temperature function of thermal conductivity was conducted using MATPRO + COBRA-EN code, by inputting negative value.

\section{THEORY}

\subsection{Description Of PWR-1000 Fuel Matrix}

PWR-1000 core[12,13] are composed of 193 fuel assemblies which each fuel assembly contains 264 fuel rods with $3.66 \mathrm{~m}$ of active length, 24 guide tubes (guide thimble) and 1 tube containing instrumentation, 2 grid holders (at the bottom and top of the fuel assemblies) and 8 spacer grids along the active fuel rods, $3411 \mathrm{MWt}$ power capacity, system pressure of $15.5 \mathrm{MPa}$, inlet coolant temperature of $288^{\circ} \mathrm{C}$ and effective coolant flow rate of $12.47 \times 10^{6}$ $\mathrm{kg} /\left(\mathrm{m}^{2} \mathrm{~h}\right)$. In general, PWR is operated safely if the fuel meat temperature is about $30 \%$ below its melting temperature $\left(2594^{\circ} \mathrm{C}\right)$ as the worst conditions of the fuel, while the minimum Departure from Nucleate Boiling Ratio (DNBR) limit are different from one PWR type to another. In PWR-1000, the minimum DNBR is $2.17[13,15]$. The rod dimension of PWR-1000 is shown in Table1.

In this research, analysis of PWR-1000 sub-channel thermal-hydraulic was performed

Table 1. Rod Dimension of PWR-1000 [13,14]

\begin{tabular}{cc}
\hline NPP type & PWR-1000 \\
\hline Fuel assembly size (cm x cm) & $21.40 \times 21.40$ \\
Total of rods & 264 \\
Space between rod center or pitch (mm) & 12.6 \\
Outside cladding diameter, OD (mm) & 9.4 \\
Cladding thickness (mm) & 0.610 \\
Gap thickness (mm) & 0.084 \\
Pellet diameter (mm) & 8.0 \\
Fuel active length (m) & 3.66 \\
Pellet density (\% theoretical density) & 95 \\
\hline
\end{tabular}

by making a comparison between the calculation using variations in fixed thermal conductivity as input data versus thermal conductivities as a function of temperature. The data used in this research are the thermal conductivities of Zircaloy-4 cladding and uranium dioxide fuel at a certain temperature during reactor operation obtained from previous studies. In the previous study using the fixed value of the thermal conductivity of the fuel provided insignificant effect on reducing the peak cladding temperature during the accident[1]. Therefore, this research needs to be performed because the valid range of thermal conductivity which involves conductivities as a function of temperature will be very useful in the analysis of advanced thermal-hydraulic of a nuclear power plant, especially in over power and/or transient condition and provides more accurate analysis results. The analysis were focused on the influence of the thermal conductivity of $\mathrm{UO}_{2}$ fuel and the Zircaloy-4 cladding in the PWR1000 core thermal-hydraulic, with the emphasizing on the effect of fuel and cladding's conductivity value on coolant temperature distribution, the temperature of outer and inner cladding,the temperature of outer and the center line ofthe fuel, and the DNBR. The calculation was performed at a steady state nominal power by comparing the results between the calculation using variations in the fixed value of thermal conductivity cladding and fuel as input data and the calculations using conductivity as a function of temperature. The calculations of fixed value of thermal conductivity were conducted using COBRA-EN code while the calculations of the conductivity as a temperature function were performed using COBRA-EN code + MATPRO[12]. As a hypothesis, several thermal-hydraulic analysis using fixed thermal conductivity were not valid for analysis due to the fuel center line temperature which out of the range compared to the ones using thermal conductivity as temperature function.

\subsection{Description of COBRA-EN Code}

The COBRA-EN code provides a capability for the thermal-hydraulics analysis oflight water reactor (LWR) type NPPs 
(bothBoilingWater Reactor (BWR) and Pressurized Water Reactor (PWR)) on steadystate and transient conditions. This code used channel and sub-channel analysis approach to determine the coolant flow and enthalpy distribution in rod bundles. The input data are the linear power, fuel rod geometry, thermal properties of fuel and cladding, primary system exit pressure, inlet mass flux for fuel channels and inlet coolant temperature. While the output dataarethe distribution of enthalpy, core pressure drop, coolant flow rate, fuel and cladding temperatures, heat flux and DNBR.

\begin{tabular}{cc}
\multicolumn{2}{c}{ Table 2. Specific heat capacities of Zircaloy-4 [12] } \\
\hline $\begin{array}{c}\text { Temperature } \\
(\mathrm{K})\end{array}$ & $\begin{array}{c}\text { Specific heat capacity } \\
\text { (J/kg K) }\end{array}$ \\
\hline 300 & 281 \\
400 & 302 \\
640 & 331 \\
1090 & 375 \\
1093 & 502 \\
1113 & 590 \\
1133 & 615 \\
1153 & 719 \\
1173 & 816 \\
1193 & 770 \\
1213 & 619 \\
1233 & 469 \\
1248 & 356 \\
\hline
\end{tabular}

There are two options when inputting the thermal properties of fuel and cladding as the input data of COBRA-EN, whether (1) the values of specific heat and thermal conductivities of fuel and cladding were fixed, or (2) the values of specific heat and thermal conductivities of fuel and cladding as a temperature functions (the value changed based on temperature reference). Specific heat and thermal conductivities of fuel and cladding as a temperature functions can be calculated using subroutine of MATPRO[15] and has been used in analysis of VVER[11] and LWR $[13,14,16]$. The LWR fuel rod cladding (zircaloy-2 or -4) have been modeled for inclusion in the MATPRO[12] material properties subroutine. Modeling approaches range from the experimental data with linear interpolation or extrapolation to a semi empirical expression suggested by theory. The data of specific heat capacity of Zircaloy-4 in MATPRO was described in Table 2.

From Table 2, the standard error for data points between 300 and $800 \mathrm{~K}$ were 1.1
$\mathrm{J} / \mathrm{kg}$.K, for data points between 800 and 1090 $\mathrm{K}$ were $2.8 \mathrm{~J} / \mathrm{kg} . \mathrm{K}$, and $10.7 \mathrm{~J} / \mathrm{kg} . \mathrm{K}$ for data points between 1090 and $1310 \mathrm{~K}[12]$.

The heat transfer from the fuel pellet to the reactor coolant depends partly on thermal conductivity of the cladding. In MATPRO, the correlation of thermal conductivity for temperature less than $2098 \mathrm{~K}$ was described in Equation 1. The standard error of the thermal conductivity of Zircaloy in Equation 4 was $1.01 \mathrm{~W} / \mathrm{m} . \mathrm{K}[12,13]$. Each notation in the equations were described in nomenclature.

$$
\begin{aligned}
& k_{Z r y}=7.51+2.09 \times 10^{-2} T_{c}-1.45 \times 10^{-5} T_{c}^{2}+\ldots \\
& \ldots+7.67 \times 10^{-9} T_{c}^{3}
\end{aligned}
$$

where $k_{Z r y}$ is thermal conductivity of Zircaloy $(\mathrm{W} / \mathrm{m} . \mathrm{K}) ; T_{c}$ is Cladding temperature (K).

In MATPRO, the specific heat capacity of fuel was modeled empirically as functions of four parameters: composition, temperature, molten fraction and oxygen to metal ratio. The correlation for specific heat of $\mathrm{UO}_{2}$ was shown in Equation (2) [12,13].

$$
\begin{aligned}
& C_{p}=\frac{K_{1} \theta^{2} \exp \left(\theta / T_{f}\right)}{T_{f}^{2}\left[\exp \left(\theta / T_{f}\right)-1\right]^{2}}+K_{2} T_{f}+\ldots \\
& \ldots+\frac{K_{3} E_{D}}{R T_{f}^{2}} \exp \left(-E_{D} / R T_{f}\right)
\end{aligned}
$$

where $C_{p}$ is specific heat capacity of $\mathrm{UO}_{2}$ $(\mathrm{J} / \mathrm{kg} . \mathrm{K}) ; K_{1}$ is constant $=296.7(\mathrm{~J} / \mathrm{kg} . \mathrm{K}) ; K_{2}$ is constant $=2.43 \times 10^{-2}\left(\mathrm{~J} / \mathrm{kg} \cdot \mathrm{K}^{-2}\right) ; K_{3}$ is constant $=8.745 \times 10^{7}(\mathrm{~J} / \mathrm{kg}) ; T_{f}$ is Fuel temperature $(\mathrm{K}) ; \mathrm{E}_{\mathrm{D}}$ is activation energy for Frenkel defect $(\mathrm{J} / \mathrm{mol}) ; R$ is universal gas constant $=8.3143(\mathrm{~J} / \mathrm{mol} . \mathrm{K})$.

It should be noted that the constants of $K_{1}, K_{2}, K_{3}, \theta$ and $E_{D}$ were determined by Equation (2) and only valid at fuel temperatures greater than $300 \mathrm{~K}$. The specific heat capacity correlation of $\mathrm{UO}_{2}$ has standard error of $\pm 3 \mathrm{~J} / \mathrm{kg} \cdot \mathrm{K}[12,13]$.

The thermal conductivity correlation of uncracked $\mathrm{UO}_{2}$ fuel in MATPRO was shown in Equation (3) $[12,13]$. 


$$
\begin{aligned}
& k_{f}=\left(\frac{D}{1+\left(6.5-0.00469 T^{\prime}\right)(1-D)}\right) \times \ldots \\
& \ldots \times\left(\frac{C_{V}}{\left(A+B T^{\prime \prime}\right)\left(1+3 e_{t h}\right)}\right)+5.2997 \times 10^{-3} \times \ldots \\
& \ldots \times T_{f}\left[\exp \left(-13358 / T_{f}\right)\right] \times\left\{1+0.169\left[\left(13358 / T_{f}\right)+2\right]^{2}\right\}
\end{aligned}
$$

where $k_{f}$ is thermal conductivity of $\mathrm{UO}_{2}$ $(\mathrm{W} / \mathrm{m} . \mathrm{K}) ; \quad D$ is the fraction of theoretical density (-); $T^{\prime}$ is porosity correction $\left(T^{\prime}=6.50-T_{f^{*}}(4.69 \times 10-3)\right.$ for temperature < $1364 \mathrm{~K}, T^{\prime}=-1$ for temperature $>1834 \mathrm{~K}$, and $T$ 'was found by interpolation for temperature in the range 1364 to $1834 \mathrm{~K}) ; A$ is a factor proportional to the point defect contribution to the phonon mean free path (m.s/kg.K). The correlation used for this factor was $0.339+$ $12.6 \times a b s o l u t e$ value $(2.0-\mathrm{O} / \mathrm{M}$ ratio $) ; T_{f}$ is fuel temperature $(K)$.

The fixed value of thermal conductivity of $\mathrm{UO}_{2}$ fuel $\left(k_{f}\right)$ in this calculation was computed using correlation as described in Equation $4[12,13]$.

$$
k_{f}=\frac{1}{11.8+0.0238 T_{f}}+8.775 \times 10^{-13} T_{f}^{3}
$$

where $k_{f}$ is thermal conductivity of $\mathrm{UO}_{2}$ (W/m.K); $T_{f}$ is Fuel temperature $(\mathrm{K})$.

\section{METHODOLOGY}

The main problem in thermal-hydraulics analysis using fixed thermal conductivity is how to determine the range of fixed thermal conductivity of fuel and cladding, so the analysis result was accepted. Consequently, analysis using fixed thermal conductivity of fuel and cladding should be compared to analysis using thermal conductivity as temperature function.

In order to obtain the accurate thermalhydraulic analysis of the PWR-1000 using COBRA-EN code, several steps are performed in this computation. First step was the preparation of input data using channel and sub-channel approach to determine the coolant flow and enthalpy distribution in rod bundles. The input data are the linear power, fuel rod geometry, thermal properties of fuel and cladding, primary system exit pressure, inlet mass flux for fuel channels and inlet coolant temperature.

In the calculation, the modeling of $1 / 8$ fuel assembly of PWR-1000 was done using the COBRA-EN code as shown in Figure 1. Each fuel rod was modeled as one subchannel. The analysis was done for the fuel center line and fuel surface temperatures of the sub-channel indicated by the maximum linear powerof $7 \mathrm{~kW} / \mathrm{ft}, 9 \mathrm{~kW} / \mathrm{ft}, 11 \mathrm{~kW} / \mathrm{ft}$ and $13 \mathrm{~kW} / \mathrm{ft}$ which equivalent to $22.96 \mathrm{~kW} / \mathrm{m}$, $29.53 \mathrm{~kW} / \mathrm{m}, 36.09 \mathrm{~kW} / \mathrm{m}$ and $42.65 \mathrm{~kW} / \mathrm{m}$ established on sub-channel number of 41, 12, 3 and 2 in Figure 1 [5,14]. The choosen of maximum linear power was in compliance with analysis by NUREG [13]. This model was used in both calculations using fixed and temperature function of thermal conductivity. The sub-channel calculation result will provide the temperature distribution of the fuel meat, cladding and coolant, heat flux and DNBR

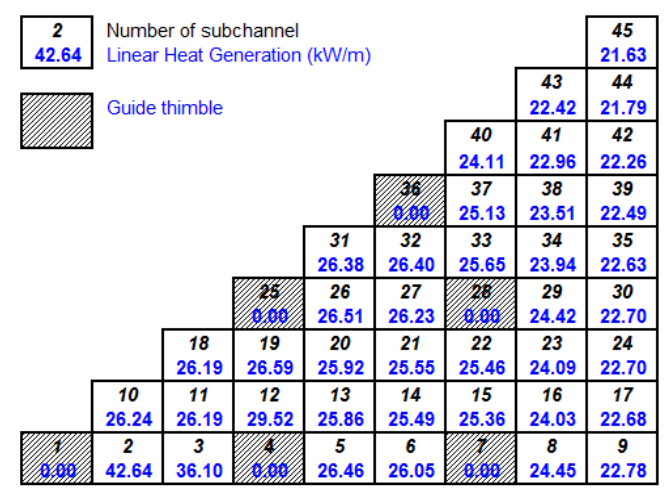

Figure 1. The 1/8 Fuel Assembly Calculation Model of COBRA-EN Code[5,13].

The second step was performing the calculationsfor thermal conductivity as temperature function using COBRA-EN code + MATPRO. The input data of thermal properties of fuel and cladding was given in negative value. So, the thermal property valuesof fueland cladding as temperature functions will be calculated using Equations (1) to (4) by MATPRO subroutine, automatically. This calculation result was applied as reference in accepting the calculation result using fixed thermal conductivity. The analysis was accepted if deviation between temperature values using 
Table 3. The Combination of The Thermal Conductivity of The Fuel and Cladding for PWR-1000 Sub-Channel Calculation Using COBRA-EN Code

\begin{tabular}{|c|c|c|c|c|c|c|}
\hline & \multirow[b]{2}{*}{$\mathrm{k}_{\mathrm{xy}}$} & \multicolumn{5}{|c|}{ Thermal Conductivity of Zircaloy-4 cladding, $k_{c}$ (W/m.K) } \\
\hline & & 13.00 & 15.57 & 16.76 & 17.94 & 18.69 \\
\hline \multirow{7}{*}{ 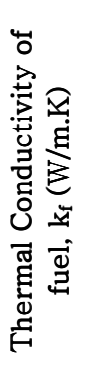 } & 5.28 & 11 & 12 & 13 & 14 & 15 \\
\hline & 3.85 & 21 & 22 & 23 & 24 & 25 \\
\hline & 3.60 & 31 & 32 & 33 & 34 & 35 \\
\hline & 3.18 & 41 & 42 & 43 & 44 & 45 \\
\hline & 2.90 & 51 & 52 & 53 & 54 & 55 \\
\hline & 2.53 & 61 & 62 & 63 & 64 & 65 \\
\hline & 2.34 & 71 & 72 & 73 & 74 & 75 \\
\hline
\end{tabular}

fixed and temperature function of thermal conductivity was in the range of $-10 \%$ to $10 \%$ [12] to avoid inaccuracy.

The third step was performing the calculation for the range values ofthermal conductivity and heat capacity of fueland cladding using the COBRA-EN code. The input data of thermal conductivity and heat capacity of fuel and cladding was given in proper value for each calculation. There were 35 combination of thermal conductivity of the fuel and cladding, as shown in Table 3.

The last step was comparing between the calculation result using thermal conductivity as temperature function and the calculation result using fixed thermal conductivity. The analysis was accepted if the deviation between both temperature was in the range of $-10 \%$ to $10 \%$ [12].

\section{RESULTS AND DISCUSSION}

The calculation of the temperature for coolant and cladding, the fuel center line $\left(\mathrm{T}_{\mathrm{cm}}\right)$ and surface of the fuel meat $\left(\mathrm{T}_{\mathrm{om}}\right)$ at nominal power were performed by using 35 models of COBRA-EN code. The calculations results using COBRA-EN code for fixed thermal conductivity and COBRA-EN code + MATPRO for thermal conductivity as temperature function are shown in Table 4. The analysis was accepted if deviation between temperature values using fixed and temperature function of thermal conductivity was in the range of $-10 \%$ to $10 \%$ [12] to avoid inaccuracy.
Table 4 shows the acceptance analysis of the fixed thermal conductivity of fuel and cladding compare to analysis using the ones as temperature function (MATPRO) for the hot sub-channel with a maximum linear power of $42.65 \mathrm{~kW} / \mathrm{m}$. The table shows that the maximum fuel center line temperature using thermal conductivity as temperature function (MATPRO) for hot sub-channel was $1717.65^{\circ} \mathrm{C}$ and taken as the reference for calculation results deviation for the maximum fuel center line temperature of fixed thermal conductivity of $5.28 \mathrm{~W} / \mathrm{m} . \mathrm{K}$ (models of 11 to 15), $3.85 \mathrm{~W} / \mathrm{m} . \mathrm{K}$ (models of 21 to 25 ), 3.60 $\mathrm{W} / \mathrm{m} . \mathrm{K}$ (models of 31 to 35 ), $3.18 \mathrm{~W} / \mathrm{m} . \mathrm{K}$ (models of 41 to 45 ), $2.90 \mathrm{~W} / \mathrm{m} . \mathrm{K}$ (models of 51 to 55 ), $2.53 \mathrm{~W} / \mathrm{m} . \mathrm{K}$ (models of 61 to 65 ) and $2.34 \mathrm{~W} / \mathrm{m} . \mathrm{K}$ (models of 71 to 75 ).

The models of 11 to 15 , models of 21 to 25 and models of 31 to 35 have maximum fuel center line temperature lower than the maximum fuel center line temperature of MATPRO and the temperature deviations were less than $-10 \%$. It means, the model of 11 to 15, models of 21 to 25 and models of 31 to 35 were not accepted for analysis.

While the models of 71 to 75 have have maximum fuel center line temperature higher than the maximum fuel center line temperature of MATPRO and the temperature deviations were more than $10 \%$. It means, the model of 71 to 75 also were not accepted for analysis. Whereas, the model of 61 and 62 have deviation of fuel center line temperature in the range of -10 to $10 \%$, but the average temperature deviation were more than $10 \%$, so the model of 61 and 62 were not accepted for the analysis. 
Table 4. The Acceptance Analysis of Fixed Thermal Conductivity of Fuel and Cladding for The Hot Sub-channel with a Maximum Linear Power of $42.65 \mathrm{~kW} / \mathrm{m}$

\begin{tabular}{|c|c|c|c|c|c|c|c|c|c|}
\hline \multirow{3}{*}{ Model } & \multicolumn{8}{|c|}{ Temperature $\left({ }^{\circ} \mathrm{C}\right)$} & \multirow{3}{*}{ Acceptance } \\
\hline & \multicolumn{2}{|c|}{ average fuel } & \multicolumn{2}{|c|}{ fuel centre line } & \multicolumn{2}{|c|}{ fuel surface } & \multicolumn{2}{|c|}{ inner clad } & \\
\hline & $\mathrm{T}$-ave $\left({ }^{\circ} \mathrm{C}\right)$ & $\operatorname{Dev}(\%)$ & $\mathrm{T}-\mathrm{cm}\left({ }^{\circ} \mathrm{C}\right)$ & $\operatorname{Dev}(\%)$ & $\mathrm{T}$-om $\left({ }^{\circ} \mathrm{C}\right)$ & $\operatorname{Dev}(\%)$ & $\mathrm{T}-\mathrm{ic}\left({ }^{\circ} \mathrm{C}\right)$ & $\operatorname{Dev}(\%)$ & \\
\hline MATPRO & 1110.55 & - & 1717.65 & - & 569.05 & - & 403.45 & - & $\begin{array}{c}\text { Reference } \\
\text { analysis }\end{array}$ \\
\hline 11 & 898.15 & -19.13 & 1187.15 & -30.89 & 586.05 & 2.99 & 420.45 & 4.21 & No \\
\hline 12 & 886.25 & -20.20 & 1175.35 & -31.57 & 574.25 & 0.91 & 408.65 & 1.29 & No \\
\hline 13 & 882.05 & -20.58 & 1171.15 & -31.82 & 570.05 & 0.18 & 404.45 & 0.25 & No \\
\hline 14 & 878.45 & -20.90 & 1167.45 & -32.03 & 566.35 & -0.47 & 400.75 & -0.67 & No \\
\hline 15 & 876.35 & -21.09 & 1165.35 & -32.15 & 564.35 & -0.83 & 398.75 & -1.16 & No \\
\hline 21 & 1014.05 & -8.69 & 1410.45 & -17.88 & 586.05 & 2.99 & 420.45 & 4.21 & No \\
\hline 22 & 1002.15 & -9.76 & 1398.65 & -18.57 & 574.25 & 0.91 & 408.65 & 1.29 & No \\
\hline 23 & 997.95 & -10.14 & 1394.35 & -18.82 & 570.05 & 0.18 & 404.45 & 0.25 & No \\
\hline 24 & 994.35 & -10.46 & 1390.75 & -19.03 & 566.35 & -0.47 & 400.75 & -0.67 & No \\
\hline 25 & 992.25 & -10.65 & 1388.65 & -19.15 & 564.35 & -0.83 & 398.75 & -1.16 & No \\
\hline 31 & 1043.75 & -6.02 & 1467.65 & -14.55 & 586.05 & 2.99 & 420.45 & 4.21 & No \\
\hline 32 & 1031.95 & -7.08 & 1455.85 & -15.27 & 574.25 & 0.91 & 408.65 & 1.29 & No \\
\hline 33 & 1027.65 & -7.46 & 1451.65 & -15.49 & 570.05 & 0.18 & 404.45 & 0.25 & No \\
\hline 34 & 1024.05 & -7.79 & 1447.95 & -15.70 & 566.35 & -0.47 & 400.75 & -0.67 & No \\
\hline 35 & 1021.95 & -7.98 & 1445.95 & -15.82 & 564.35 & -0.83 & 398.75 & -1.16 & No \\
\hline 41 & 1104.15 & -0.58 & 1584.15 & -7.77 & 586.05 & 2.99 & 420.45 & 4.21 & Yes \\
\hline 42 & 1092.35 & -1.64 & 1572.35 & -8.46 & 574.25 & 0.91 & 408.65 & 1.29 & Yes \\
\hline 43 & 1088.15 & -2.02 & 1568.05 & -8.71 & 570.05 & 0.18 & 404.45 & 0.25 & Yes \\
\hline 44 & 1084.45 & -2.35 & 1564.45 & -8.92 & 566.35 & -0.47 & 400.75 & -0.67 & Yes \\
\hline 45 & 1082.35 & -2.54 & 1562.35 & -9.04 & 564.35 & -0.83 & 398.75 & -1.16 & Yes \\
\hline 51 & 1154.15 & 3.93 & 1680.45 & -2.17 & 586.05 & 2.99 & 420.45 & 4.21 & Yes \\
\hline 52 & 1142.35 & 2.86 & 1668.65 & -2.85 & 574.25 & 0.91 & 408.65 & 1.29 & Yes \\
\hline 53 & 1138.15 & 2.49 & 1664.45 & -3.10 & 570.05 & 0.18 & 404.45 & 0.25 & Yes \\
\hline 54 & 1134.45 & 2.15 & 1660.75 & -3.31 & 566.35 & -0.47 & 400.75 & -0.67 & Yes \\
\hline 55 & 1132.45 & 1.97 & 1658.75 & -3.43 & 564.35 & -0.83 & 398.75 & -1.16 & Yes \\
\hline 61 & 1237.25 & 11.41 & 1840.45 & 7.16 & 586.05 & 2.99 & 420.45 & 4.21 & No \\
\hline 62 & 1225.45 & 10.35 & 1828.75 & 6.47 & 574.25 & 0.91 & 408.65 & 1.29 & No \\
\hline 63 & 1221.25 & 9.97 & 1824.45 & 6.22 & 570.05 & 0.18 & 404.45 & 0.25 & Yes \\
\hline 64 & 1217.55 & 9.63 & 1820.85 & 6.01 & 566.35 & -0.47 & 400.75 & -0.67 & Yes \\
\hline 65 & 1215.45 & 9.45 & 1816.75 & 5.89 & 564.35 & -0.83 & 398.75 & -1.16 & Yes \\
\hline 71 & 1290.25 & 16.17 & 1942.35 & 13.08 & 586.05 & 2.99 & 420.45 & 4.21 & No \\
\hline 72 & 1278.35 & 15.11 & 1930.55 & 12.39 & 574.25 & 0.91 & 408.65 & 1.29 & No \\
\hline 73 & 1274.05 & 14.72 & 1926.35 & 12.15 & 570.05 & 0.18 & 404.45 & 0.25 & No \\
\hline 74 & 1270.45 & 14.40 & 1922.65 & 11.94 & 566.35 & -0.47 & 400.75 & -0.67 & No \\
\hline 75 & 1268.35 & 14.21 & 1920.65 & 11.82 & 564.35 & -0.83 & 398.75 & -1.16 & No \\
\hline
\end{tabular}

Consequently, in the results of the evaluation of thermal-hydraulics parameters [3], the maximum fuel center line temperature of AP1000 reactor should be corrected 15\% higher.

Furthermore, the maximum fuel center line temperature using fixed thermal conductivity of models of 41 to 45 , models of 51 to 55 and models of 63 to 65 have temperature deviations within $-10 \%$ to $10 \%$ if compare to reference. The combinations of fixed fuel thermal conductivity in the range of
$3.18-2.90 \mathrm{~W} / \mathrm{m} . \mathrm{K}$ and cladding thermal conductivity in the range of $13.00-18.69$ W/m.K (models of 41 to 45 and models of 51 to 55) were accepted for analysis. And the combinations of fixed fuel thermal conductivity value of $2.53 \mathrm{~W} / \mathrm{m} . \mathrm{K}$ and cladding thermal conductivity in the range of 16.76 $18.69 \mathrm{~W} / \mathrm{mK}$ (models of 63 to 65 ) were also accepted for analysis. 


\section{CONCLUSION}

The analysis of PWR-1000 sub-channel thermal-hydraulic using COBRA-EN code for finding the accurate fixed thermal conductivities value of fuel and cladding has been carried out, by comparing to the analysis one using thermal conductivity as temperature functions using COBRA-EN code + MATPRO. The analysis using fixed thermal conductivity was accepted, if the deviation of the temperature was in the range of $-10 \%$ to 10 $\%$. Hence, the analysis was accurate, if the calculation using combination of the fixed fuel thermal conductivity in the range of 3.18 $2.90 \mathrm{~W} / \mathrm{m} . \mathrm{K}$ and cladding thermal conductivity variation of 13.00 - $18.69 \mathrm{~W} / \mathrm{m} . \mathrm{K}$, and the calculation using combination of the fuel thermal conductivity of $2.53 \mathrm{~W} / \mathrm{m} . \mathrm{K}$ and cladding thermal conductivity variation of 16.76 - $18.69 \mathrm{~W} / \mathrm{mK}$.

\section{ACKNOWLEDGEMENT}

This research was funded by the Center of Nuclear Reactor Technology and Safety in BATAN's DIPA 2015/ Number: SP DIPA 080.01.1.450310/2015.

\section{REFERENCES}

[1] Terrani K.A., Wang D., Ott L.J., Montgomery R.O. "The Effect of Thermal Conductivity on the Behavior of LWR Cores during Loss-of-Coolant Accidents". Journal of Nuclear Materials, vol. 448, 2014, 512-519.

[2] Aghaie M., Zolfaghari A., Minuchehr M., Norouzi A. "Enhancement of COBRA-EN Capability for VVER Reactor Calculations”. Annals of Nuclear Energy 46, 2012, 236-243.

[3] Isnaini M.D., Dibyo S., Suroso, Geni R.S., Endiah P.H., Subekti M.. "Evaluasi Parameter Desain Termohidrolika Teras dan Subkanal PLTN AP1000 pada Kondisi Tunak". Jurnal Tek. Reaktor Nuklir Tri Dasa Mega, Vol. 14 No.1, 2012, 14-28.

[4] Isnaini M.D.. "Pengaruh Grid Pejarak dan Nozzle terhadap Parameter Termohidrolika Perangkat Bahan Bakar Reaktor AP1000”. Jurnal Tek. Reaktor Nuklir Tri Dasa Mega, Vol. 15 No.3, 2013, 159-170.
[5] Isnaini M.D., Surip Widodo, Subekti M. "ThermalHydraulics Analysis on Radial and Axial Power Fluctuation for AP1000 Reactor". Jurnal. Tek. Reaktor Nuklir Tri Dasa Mega. Vol. 17 No.2. 2015, 79-86.

[6] Rahmani Y., Pazirandeh A., Ghofrani M.B., Sadighi M.. "Calculation of the Deterministic Optimum Loading Pattern of the BUSHEHR VVER-1000 Reactor Using the Weighting Factor Method". Annals of Nuclear Energy 49, 2012, 170-181.

[7] Zarifi E., Jahanfarnia G., Veysi F. "ThermalHydraulics Modeling of Nanofluids as the Coolant in VVER-1000 Reactor Core by the Porous Media Approach". Annals of Nuclear Energy 51, 2013, 203-212.

[8] Zarifi E., Jahanfarnia G., Veysi F. "Sub-channel Analysis of Nanofluids Application to VVER-1000 Reactor". Chemical Engineering Research and Design 91, 2013, 625-632.

[9] Faghihi F., Mirvakili S.M., "Shut-down Margin Study for the Next Generation VVER-1000 Reactor Including $13 \times 13$ Hexagonal Annular Assemblies". Annals of Nuclear Energy 38, 2011, 2533-2540.

[10] Kalkhoran O.N., Minuchehr A., Shirani A.S., Rahgoshay M. "Full Scope Thermal-Neutronic Analysis of LOFA in a VVER-1000 Reactor Core by Coupling PARCS v2.7 and COBRA-EN". Progress in Nuclear Energy 74, 2014, 193-200.

[11] Rahgoshay M., Tilehnoee M.H., "Optimizing a Gap Conductance Model Applicable to VVER-1000 Thermal-Hydraulic Model". Annals of Nuclear Energy 50, 2012, 263-267.

[12] Siefken L.J., Coryell E.E., Harvego E.A., Hohorst J.K. "MATPRO - A Library of Materials Properties for Light Water Reactor Accident Analysis". NUREG/CR-6150, Vol. 4, Rev.2, 2001.

[13] Isnaini M.D., Subekti M., "Validation Of Simbat-PWR Using Standard Code of COBRA-EN on Reactor Transient Condition". Jurnal Tek. Reaktor Nuklir Tri Dasa Mega Vol. 18 No.1, 2016, 41-50.

[14] O'donnell G.M., Scott H.H., Meyer R.O. "A New Comparative Analysis of LWR Fuel Designs". NUREG-1754, 2001.

[15] Shuffler C., Trant J., Malen J., Todreas N. "Thermal hydraulic analysis for grid supported pressurized water reactor cores", Nuclear Engineering and Design 239, 2009, 1442-1460.

[16] Ott L.J., Robb K.R., Wang D. "Preliminary Assessment of Accident-Tolerant Fuels on LWR Performance During Normal Operation and Under DB and BDB Accident Condition", Journal of Nuclear Materials 448, 2014, 520-533. 